\title{
Potential value of biochar as a soil amendment: A review
}

\author{
Muhammad Irfan ${ }^{1 *}$, Rafiullah $^{1}$, Farah Naz Kaleri², Muhammad Rizwan ${ }^{3}$ \\ and Imran Mehmood ${ }^{4}$ \\ 1. Department of Soil and Environmental Sciences, The University of Agriculture, Peshawar- Pakistan \\ 2. Department of Biotechnology, Sindh Agriculture University, Tandojam-Pakistan \\ 3. Department of Soil and Water Sciences, China Agricultural University, Beijing-China \\ 4. Department of Plant Nutrition, China Agricultural University, Beijing-China \\ *Corresponding author's email: mirfan180@yahoo.com
}

Citation

Muhammad Irfan, Rafiullah, Farah Naz Kaleri, Muhammad Rizwan and Imran Mehmood. Potential value of biochar as a soil amendment: A review. Pure and Applied Biology. Vol. 6, Issue 4, pp1494-1502.

http://dx.doi.org/10.19045/bspab.2017.600161

\begin{tabular}{llll}
\hline \hline Received: 07/08/2017 & Revised: 16/11/2017 & Accepted: 28/11/2017 & Online First: 08/12/2017 \\
\hline
\end{tabular}

\section{Abstract}

This article reviews a range of beneficial impacts of biochar on soil physico-chemical properties and crop yield. Advances in biochar research appeal for identification of beneficial effect of biochar using as a soil amendment before any large-scale field application is recommended. Thus, the purpose of this review are to evaluate the potential beneficial effect of biochar using as a soil amendment. Biochar, a product of biomass pyrolysis, and is usually characterized as rich in recalcitrant $\mathrm{C}$, with a large surface area, and diverse functional groups, although these features largely depend on the feedstock and pyrolysis conditions. Pyrolysis is a thermochemical process that transforms biomass into biochar, bio-oil, and syngas. The use of biochar as a soil amendment has received growing attention due to its ability to enhance crop productivity and improve physicochemical properties of soil. Compared to other soil amendments, the high surface area and porosity of biochar enable it to adsorb or retain nutrients, contaminants and water and also provide a habitat for beneficial micro-organisms. Generally, the ash fraction of biochar consisted of nutrients including $\mathrm{N}, \mathrm{P}, \mathrm{K}, \mathrm{S}, \mathrm{Ca}, \mathrm{Mg}, \mathrm{Mn}, \mathrm{Fe}$, and $\mathrm{Zn}$ which are required for plant growth. Although biochar has the potential value to use as a soil amendment but still need efficient road-map for biochar production, classification, and its effect in different soil-environment and cost-benefit analysis, must be developed before implementation of field-scale application.

Keywords: Biochar, Pyrolysis; Soil amendment; Agronomic benefits; Pollutants

\section{Introduction}

Biochar is the product of thermal degradation of organic materials in the absence of air (pyrolysis), and is distinguished from charcoal by its use as a soil amendment. It is a $\mathrm{C}$ rich material produced thorough pyrolysis process by heating any biomass like manure, organic wastes, bioenergy crops (grasses, willows) and crop residues. Biochar production is a simple tool that can (1) enhance soil fertility by improving its physico-chemical properties (2) combat global warming (3) reduce organic/ agricultural waste; and (4) produce renewable energy (syngas and bio-oil).

The chemical composition of feedstock and pyrolysis temperature has a significant influence on biochar properties because each 
feedstock has different elemental composition and their thermal degradation at different temperature differs consequently. Characterizing the properties of biochar from different biomass materials under different production conditions will enable a mechanistic understanding of the effects of different biochars on soil properties and crop nutrients. Therefore, characterizing the properties of biochar is important before its use in agriculture and environmental management (Figure 1).

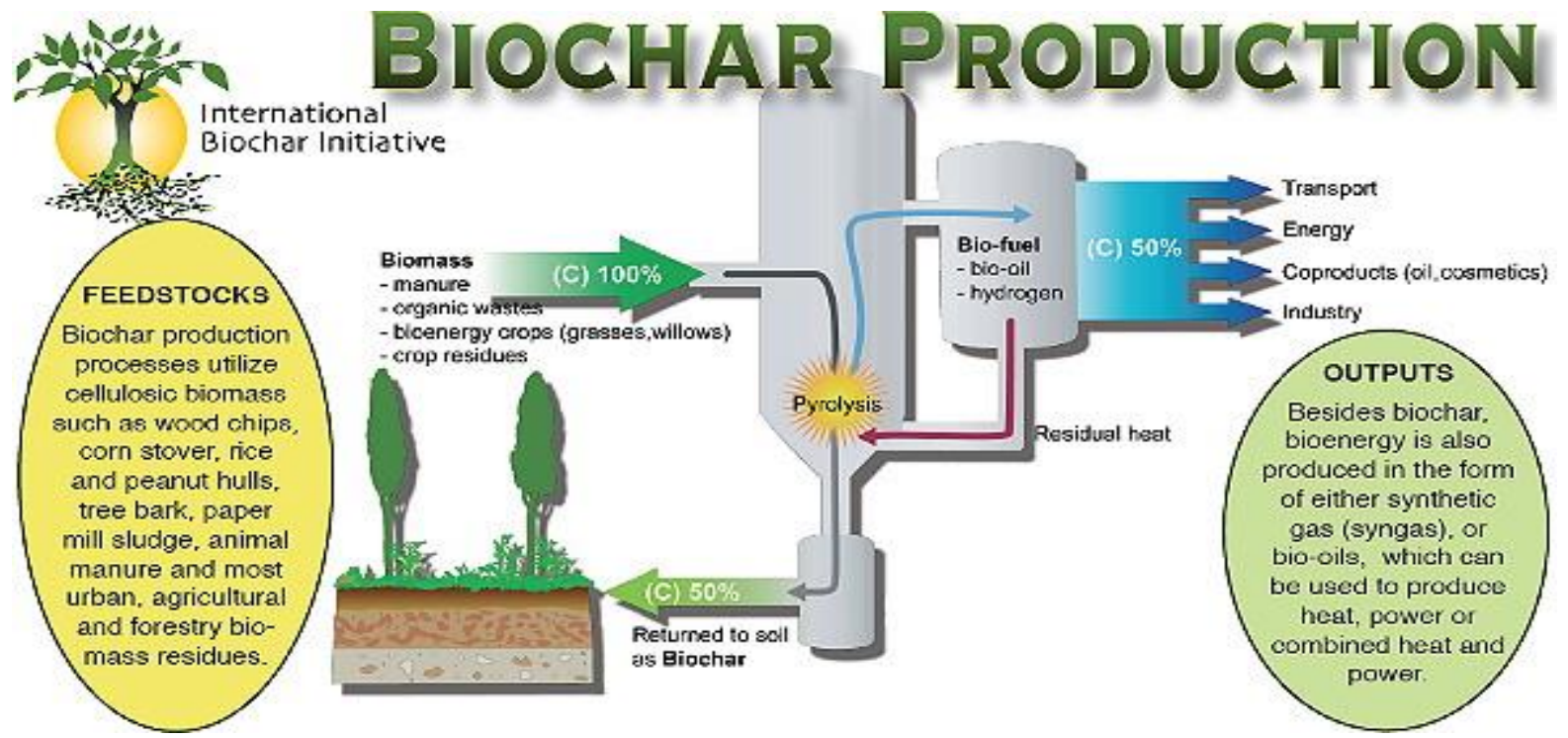

Figure 1. Diagram showing biochar production processes (From International Biochar Initiative)

\section{Effect of Feedstock on biochar properties}

Different kind of biomass feedstock wood material, crop residues, switchgrass, organic wastes and animal manure can be used for biochar production $[1,2]$. Composition of feedstock refers to the cellulose, hemicellulose and lignin component of biomass. The breakdown rate of these each component is different. The organic components of biomass cellulose, hemicelluloses and lignin material are considering a key factor for establishing suitable temperature and feedstock for biochar and bio-fuel production. Yang et al. [3] reported that cellulose and hemicellulose decompose at $220-400{ }^{\circ} \mathrm{C}$, whereas lignin is resistant to decomposition above $400{ }^{\circ} \mathrm{C}$. Furthermore, biochar originates from the lignin component of the biomass, whereas bio-oil comes from cellulose at a pyrolysis temperature of $500{ }^{\circ} \mathrm{C}$.
The biochar derived from manure is typically rich in soil nutrients such as $\mathrm{N}, \mathrm{P}, \mathrm{Ca}, \mathrm{Mg}$, and $\mathrm{K}$ [4-7]. The primary reason for the application of wastewater sludge for biochar production and agricultural utilization is higher concentrations of $\mathrm{N}$ and $\mathrm{P}$ in wastewater sludge biochar, as well as other micro and macronutrients [8]. More recently, [9] reported Achnatherum splendens L. biomass for biochar production and found high ash content in biochar obtained at $700{ }^{\circ} \mathrm{C}$ indicating that a significant amount of mineral nutrients are present in biochar and offers a greater potential as a soil amendment. The digested and undigested biomass derived biochar have significantly different surface area. The digested biomass derived biochar had significant $\mathrm{N}_{2}$ surface area $\left(336 \mathrm{~m}^{2} / \mathrm{g}\right)$ and biochar from undigested biomass was very small $\left(2.60 \mathrm{~m}^{2} / \mathrm{g}\right)$ respectively [10]. Keiluweit et al. [11]. 2010 reported surface 
area values for wood char $\left(347 \mathrm{~m}^{2} / \mathrm{g}\right)$ were $\quad\left(140 \mathrm{~m}^{2} / \mathrm{g}\right)$ (Figure 2). significantly higher than those of grass char
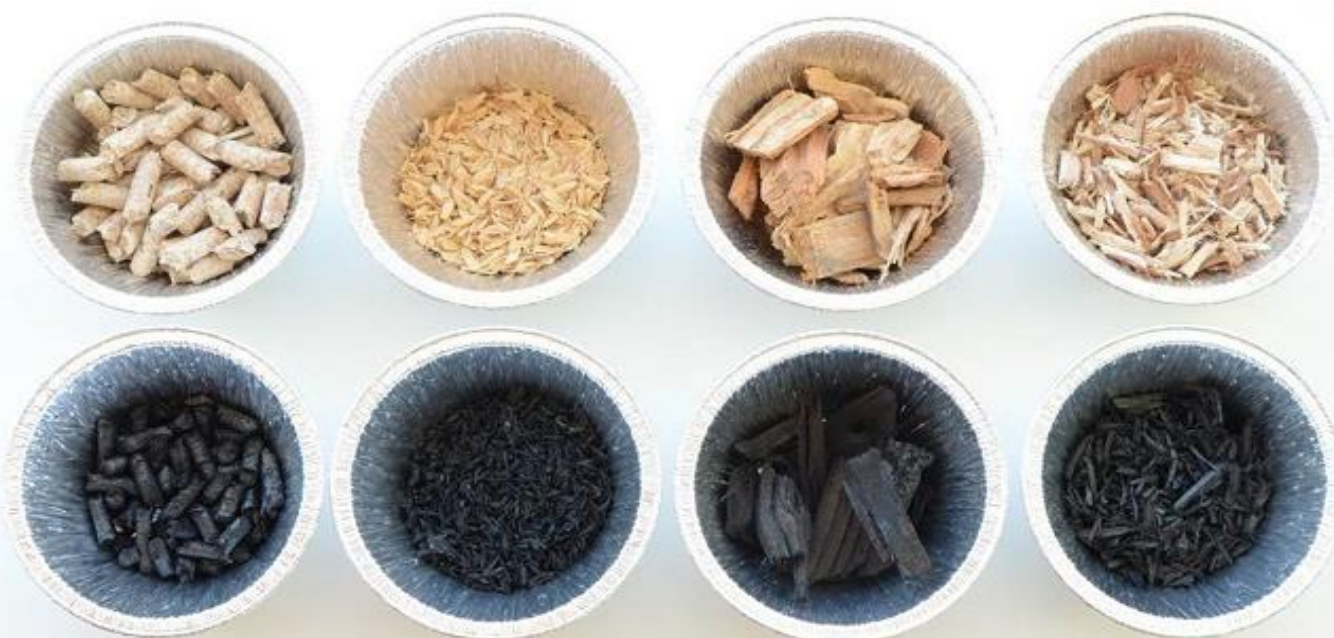

Figure 2. Different feedstocks and their biochars. Ondrej Masek, UK Biochar Research Centre (UKBRC)

\section{Effect of pyrolysis temperature on biochar properties}

The properties of biochar are not only a function of the raw feedstock but are also dependent on the pyrolysis conditions, such as temperature, heating rate, and residence time. The $\mathrm{C}$ contents in the biochars were $58 \%, 62 \%$, and $64 \%$ at 300,500 , and $700{ }^{\circ} \mathrm{C}$, indicating that the biochar became more carbonaceous as temperature was increased [9]. The biochar produced at high pyrolysis temperature indicate an increase in aromaticity and a decrease in polarity [12]. By using X-ray diffraction analysis, the authors concluded that increasing pyrolysis temperature, cellulose loss and crystalline mineral components increased. Ahmad et al. [13] reported that carbon content in biochar increased and $\mathrm{H}, \mathrm{N}$, and $\mathrm{O}$ contents decreased with increasing pyrolysis temperature, which indicate high carbonization at elevated temperature. The molar ratios of elements can be calculated to estimate the aromaticity $(\mathrm{H} / \mathrm{C})$ and polarity $(\mathrm{O} / \mathrm{C},(\mathrm{O}+\mathrm{N}) / \mathrm{C}$, and $(\mathrm{O}$ $+\mathrm{N}+\mathrm{S}) / \mathrm{C}$ ) of the biochar. The molar ratios of elements suggested an increased in aromaticity and a decreased in polarity of biochar with increasing pyrolysis temperature [13]. Increasing pyrolysis temperature results in decreased nitrogen content due to volatilization and increased cation exchange capacity [14], and carbon content, surface area, and ash content in biochar [1].

In general, the cation exchange capacity (CEC) of most biochars is relatively high, in part due to their negative surface charge and resultant affinity for soil cations. With increasing temperature, a dramatic rise in both porosity and surface area was observed $[11,15]$. The increased pyrolysis temperature and harsh pyrolysis conditions result in a growing proportion of biochar particles with smaller particle size distributions and recognized different size ranges of pores in biochar particles with scanning electron microscope (SEM) images and with each playing an vital role for the adsorption property of porous material [16]. The ash content of biochar increase with pyrolysis temperature due to concentration of mineral compound in biochar during pyrolysis processes [5]. Usually, with increasing pyrolysis temperature, biochar $\mathrm{pH}$ increased 
due to separating of alkali salts from organic compounds and liming induced by decreasing acidic functional groups and subsequently, increasing basic functional groups $[17,18]$. A number of studies indicated that high pyrolysis temperature led to increased surface area and porosity due to escape of volatiles [13, 17]. Irfan et al. [9] found increasing trend in $\mathrm{pH}, \mathrm{EC}$ and ash content with increasing pyrolysis temperature. So, both feedstock source and pyrolysis temperature decide the final properties of biochar (Figure 3).

\section{Biochar as a soil amendment}

A part from being a $\mathrm{C}$ source, biochar has been shown to produce changes in the soil chemical, physical properties and enhance plant growth when used as an organic soil amendment. The higher productivity of "Terra Preta" soils that were regularly amended with biochar and other organic materials than un-amendment soil, led to world-wide interest in applying biochar to agricultural soils.

Increasing data show that amending soil with biochar has remarkable effects on the physical, chemical, and microbiological properties of soil [19-21]. The most notable effects may be the increase in the stable soil $\mathrm{C}$ pool and reduced greenhouse gas emissions [22,23]. Thus, amending soil with biochar is a way to sequester $\mathrm{C}$ due to the persistence of biochar-C in soil

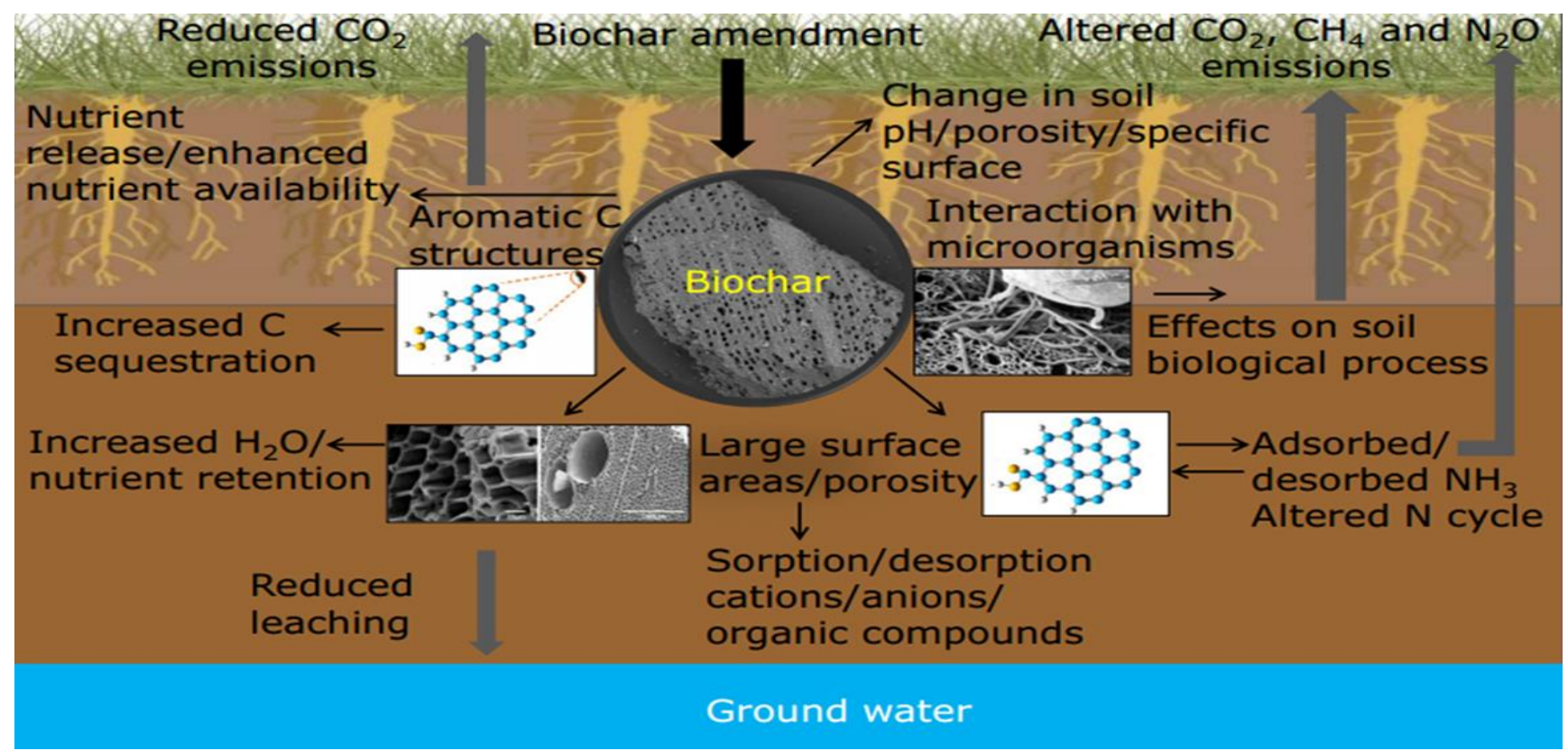

\section{Figure 3. Multi-dimensional benefits of biochar an agriculture and environment}

\section{Biochar effect on soil physical Properties}

Several incubation and long term field experiment showed that soil bulk density decreased with addition of biochar [24] and more recent study, [25] reported decreased in bulk density of sandy loam soil by addition of biochar. Further the author found increase in aggregate stability by $7-9 \%$ and $17-20 \%$ after two growing seasons. Application of rice hull derived biochar increased the percentage of water stable aggregates by 36$69 \%$ [26]. Amendment of soil with biochar had a remarkable improvement in water stable aggregate [27]. From literature study, [21] concluded that amendment soil with about $\sim 2 \%(\mathrm{w} / \mathrm{w})$ rate of biochar appears to be enough to decrease bulk density of soil. Biochar application rate of $0-20 \mathrm{~g} \cdot \mathrm{kg}^{-1}$ 
significantly increased specific surface area from 130 to $150 \mathrm{~m}^{2} \mathrm{~g}^{-1}$ respectively [24]. Compared with freshly added biochars, aged biochar typically tend to have higher surface area due to various interaction types with soil [17]. The surface area of soil is an important physical property which effect nutrient and water holding capacity, microbial activity and soil aeration.

Additionally, amending soil with biochar has significant effect on soil hydrological properties (i.e., moisture content, water holding capacity, water retention, hydraulic conductivity, water infiltration rate), and these properties are perpetually related to bulk density, surface area, porosity and aggregate stability. Recently, biochar incorporation at 22 tha $^{-1}$ increased waterholding capacity by $11 \%$ and $14 \%$, waterretention capacity by $28 \%$ and $32 \%$ under the Kubuqi and the Thar Desert soils as compared with the control soil [28]. Biochar application resulted significant increases in water infiltration $\left(0.157-0.219 \mathrm{~mL} \mathrm{~min}^{-1}\right)$ as compared to control. Biochar treatment led to increased soil water holding capacity, particularly at lower tensions in the Typic Fragiaqual soil, suggesting that these biochars may facilitate drainage in the poorly drained soil. Furthermore, biochar addition significantly increased macroporosity and mesoporosity [29].

\section{Biochar effect on soil chemical Properties}

Beside changes in soil physical properties, biochar incorporation can alter soil chemical properties as well as increase nutrients availability for plant growth. The favorable effect of biochar on soil chemical properties may occur by (i) increases in cation exchange capacity (CEC) [30]; (ii) sorption of heavy metals [31]; and (iii) immobilization of toxic organic and inorganic compounds in soil $[32,33]$. The most pronounced beneficial effect of biochar occurred an acidic soil acting as a liming agent by increased $\mathrm{pH}$ and decreased exchangeable Al [34]. Jeffery et al.
[35] confirmed from meta-analysis that biochar greatest positive effect occur in acidic and neutral $\mathrm{pH}$ soils and may be liming effect of biochar in soil is driving mechanism an increase in crop yield.

Soil amending with biochar increased C, N, available $\mathrm{P}, \mathrm{pH}, \mathrm{CEC}$ and exchangeable cations (e.g. $\mathrm{Ca}, \mathrm{Mg}, \mathrm{Na}$, and $\mathrm{K}$ ) in soil [36]. Also, an another study, increases in $\mathrm{pH}$, organic carbon, and exchangeable $\mathrm{Na}, \mathrm{K}$, and $\mathrm{Ca}$ as well as extractable $\mathrm{P}$ but decreases in exchangeable $\mathrm{Al}$ in soil as result of amending biochar produced from green waste [36]. Additionally, these changes to soil properties was roughly proportional to the rate of biochar application (e.g. increases with increasing rate of biochar application). SOC is one of the key indicator of soil quality that may improve degraded, highly weather and nutrient poor soil. More recently, some studies have confirmed that biochar using as a soil amendment improved soil organic carbon and total nitrogen [37,38]. Several study have shown that biochar amendment can enhance total N [39-41].

\section{Biochar effect on soil biota}

There is some evidence from scientific literature that soil microbial communities are responsive to biochar amendment. Biochar incorporation to soil has been suggested as a strategy to improve crop productivity and soil quality, which may also affect microbial activity. It is well documented that biochar physico-chemical properties as well as induced changes by biochar in soil physicochemical can change the activities of soil microorganisms. Biochar is porous body where pores serve as habitat for soil microorganisms $[42,43]$. It can be concluded from the study of [43] that biochar macropores $(>200 \mathrm{~nm})$ are the right size to accommodate bacteria which probably represent most of the protected microbial habitats. The biochar production temperature determine the size of these pores, where at elevated temperature organic matter 
volatilized creating larger pores. Moreover, the pore size and abundance is also determined by the biochar feedstock. The biochar greater surface area leads to more chances for microbial colonization. The biochar chemical properties like (1) its surface charge, which binds microbial cells, chemical compounds and ions, and (2) the concentration of nutrients and DOC that are desorbed or solubilized from the biochar, can account for microbial growth on biochar surfaces and within its pores [44]. According to [44] that biochar $\mathrm{pH}$ as well as the nature of the DOC and other metabolisable C compounds are likely to be important controllers of microorganisms growing on biochars. Moreover, biochar surface, porosity and the size can exemplifies a suitable niche for microbial colonization, where biochar does not provide microorganisms with as much mineralizable $\mathrm{C}$ and nutrient sources as the bulk soil.

\section{Biochar for remediation of contaminated soil}

Biochar has recently been recommended to remediate contaminated soil by sorption of both heavy metal and organic pollutants and reduce their mobility. Cao et al. [5] tested the capability of biochar produced from dairy manure at $500{ }^{\circ} \mathrm{C}$, in removing $\mathrm{Pb}$ and atrazine from aqueous solution. The biochar exhibited significant ability of adsorption for $\mathrm{Pb}$ and atrazine, with $\mathrm{Pb}$ and atrazine removal by as high as $100 \%$ and $77 \%$, respectively. The author concluded that dairy manure can be converted into biochar as an effective adsorbent for application in environmental remediation. More recently, [45] suggested the long-term effectiveness and potential of biochar application in immobilising heavy metals in contaminated soil. It was investigated that the freely dissolved concentration of PAH in sewage sludge can significantly decrease in the presence of biochar, with the $0-57 \%$ reduction depending on the added amount of biochar [46].
Oleszczuk et al. [47] inspected the sorption of the terbuthylazine in biochar-amended soils and found that the adsorption coefficient increased by 63 and 2.7 times in the $\mathrm{BC} 700$ and $\mathrm{BC} 350$ biochar amendment soil respectively. Based on many published research reports, two important mechanism such as surface adsorption and partition is responsible for organic pollutants removal. Adsorption refers to the surface interactions leading to adhesion of pollutant molecules to biochar surfaces, whereas sorption includes both surface adsorption as well as partition of pollutant molecules in the micropores of biochar (without differentiating the two processes).

\section{Biochar as a nutrients source}

Biochar can serve as a direct nutrient supply or indirectly increase soil nutrients availability. Smider et al. [40] reported agronomic performance of a high ash biochar produced from tomato green waste by incorporation into soil resulted increased in the shoot dry matter of corn. The increased in shoot dry matter of corn was attributed to release of nutrients from the biochar and biochar liming effect and associated increased availability of nutrients. Generally, the ash fraction of biochar consisted of nutrients including $\mathrm{N}, \mathrm{P}, \mathrm{K}, \mathrm{S}, \mathrm{Ca}, \mathrm{Mg}, \mathrm{Mn}$, $\mathrm{Fe}$, and $\mathrm{Zn}$ which are required for plant growth. In a greenhouse experiment, radish yields (up to 96\%) increases from application of biochar produced from poultry litter and suggested that this increased yield was mainly due to the biochar's ability to increase $\mathrm{N}$ availability [36]. During the two rice/wheat rotations, seasonal application of $4.5 \mathrm{t} \mathrm{ha}^{-1}$ and $9.0 \mathrm{t} \mathrm{ha}^{-1}$ biochar increased the total rice/wheat crop biomass $24.3 \%$ and $34.3 \%$, respectively [41]. However, not all soils demonstrate broader improvements, and not all crops behave in the same way with biochar amendment [48]. Güereña et al. [49] reported that biochar addition did not improve maize yield and plant $\mathrm{N}$ uptake. In fact, some 
biochars may have adverse effects on plant growth, and not all soils respond to biochar additions in the same way.

\section{Conclusions}

Biochar is seen to be beneficial an improving soil physico-chemical properties, soil biota, crop productivity and remediating contaminated soil and recycling agricultural wastes. Biochar, using as a soil amendment have multiple benefits, interlinked and include both direct and indirect effect. Therefore, biochar can be potentially an attractive soil amendment in modern agriculture to solve food and environmental problems. Obviously further research is needed to evaluate full potential of biochar as a soil amendment with possibly various benefits to the agriculture and environment.

\section{Author contribution}

Critically reviewed the manuscript: M Irfan, Rafiullah, FN Kaleri, M Rizwan \& I Mehmood, Analyzed the data: M Irfan, Rafiullah, FN Kaleri, M Rizwan \& I Mehmood, Contributed reagents/ materials/ analysis tools: M Irfan, FN Kaleri \& Rafiullah, Wrote the paper: M Irfan, Rafiullah \& FN Kaleri.

\section{References}

1. Novak JM, Lima I, Xing B, Gaskin JW, Steiner C, Das K, Ahmedna M, Rehrah D, Watts DW \& Busscher WJ (2009). Characterization of designer biochar produced at different temperatures and their effects on a loamy sand. Ann Environ Sci 3: 2.

2. Pituello C, Francioso O, Simonetti G, Pisi A, Torreggiani A, Berti A \& Morari F (2015). Characterization of chemical-physical, structural and morphological properties of biochars from biowastes produced at different temperatures. $J$ Soils \& Sediments 15: 792.

3. Yang H, Yan R, Chin T, Liang DT, Chen H \& Zheng C (2004). Thermogravimetric analysis-Fourier transform infrared analysis of palm oil waste pyrolysis. Energy \& Fuels 18: 1814.
4. Cantrell KB, Hunt PG, Uchimiya M, Novak JM \& Ro KS (2012). Impact of pyrolysis temperature and manure source on physicochemical characteristics of biochar. Bioresour Technol 107: 419.

5. Cao X, \& Harris W (2010). Properties of dairy-manure-derived biochar pertinent to its potential use in remediation. Bioresour Technol 101: 5222.

6. Dias BO, Silva CA, Higashikawa FS, Roig A \& Sánchez-Monedero MA (2010). Use of biochar as bulking agent for the composting of poultry manure: Effect on organic matter degradation and humification. Bioresour Technol 101: 1239.

7. Uzoma KC, Inoue M, Andry H, Fujimaki H, Zahoor A \& Nishihara E (2011). Effect of cow manure biochar on maize productivity under sandy soil condition. Soil Use \& Manag 27: 205.

8. Hossain MK, Strezov V, Chan KY, Ziolkowski A \& Nelson PF (2011). Influence of pyrolysis temperature on production and nutrient properties of wastewater sludge biochar. $J$ Environ Manage 92: 223.

9. Irfan M, Chen Q, Yue Y, Pang R, Lin Q, Zhao X \& Chen H (2016). Co-production of biochar, bio-oil and syngas from halophyte grass (Achnatherum splendens L.) under three different pyrolysis temperatures. Bioresour Technol 211: 457.

10. Yao Y, Gao B, Inyang M, Zimmerman AR, Cao X, Pullammanappallil P \& Yang L (2011). Biochar derived from anaerobically digested sugar beet tailings: Characterization and phosphate removal potential. Bioresour Technol 102: 6273.

11. Keiluweit M, Nico PS, Johnson MG \& Kleber M (2010). Dynamic Molecular Structure of Plant Biomass-Derived Black Carbon (Biochar). Environ Sci Technol 44 : 1247.

12. Al-Wabel MI, Al-Omran A, El-Naggar AH, Nadeem M \& Usman AR (2013). Pyrolysis temperature induced changes in characteristics and chemical composition of biochar produced from conocarpus wastes. Bioresour Technol 131: 374. 
13. Ahmad M, Lee SS, Dou XM, Mohan D, Sung JK, Yang JE \& Ok YS (2012). Effects of pyrolysis temperature on soybean stover- and peanut shell-derived biochar properties and TCE adsorption in water. Bioresour Technol 118 : 536.

14. Gaskin J, Steiner C, Harris K, Das K \& Bibens B (2008). Effect of lowtemperature pyrolysis conditions on biochar for agricultural use. Trans Asabe 51: 2061.

15. Bird MI, Wurster CM, de Paula Silva PH, Bass AM \& De Nys R (2011). Algal biochar-production and properties. Bioresour Technol 102 : 1886.

16. Kim KH, Kim JY, Cho TS \& Choi JW (2012). Influence of pyrolysis temperature on physicochemical properties of biochar obtained from the fast pyrolysis of pitch pine (Pinus rigida). Bioresour Technol 118: 158.

17. Mukherjee A, Zimmerman A \& Harris W (2011). Surface chemistry variations among a series of laboratory-produced biochars. Geoderma 163: 247.

18. Usman AR, Abduljabbar A, Vithanage M, Ok YS, Ahmad M, Elfaki J, Abdulazeem SS \& Al-Wabel MI (2015). Biochar production from date palm waste: Charring temperature induced changes in composition and surface chemistry. J Anal Appl Pyrolysis 115: 392.

19. Chintala R, Mollinedo J, Schumacher TE, Malo DD \& Julson JL (2014). Effect of biochar on chemical properties of acidic soil. Arch Agron Soil Sci 60: 393.

20. Masto RE, Kumar S, Rout T, Sarkar P, George J \& Ram L (2013). Biochar from water hyacinth (Eichornia crassipes) and its impact on soil biological activity. Catena 111: 64.

21. Mukherjee A, \& Lal R (2013). Biochar impacts on soil physical properties and greenhouse gas emissions. Agron J 3: 313.

22. Liu $Y$, Yang $M, W u ~ Y$, Wang $H$, Chen $Y \&$ $\mathrm{Wu}$ W (2011)Reducing $\mathrm{CH}_{4}$ and $\mathrm{CO}_{2}$ emissions from waterlogged paddy soil with biochar. J Soils Sediments 1: 930.

23. Van Zwieten L, Kimber S, Morris S,
Downie A, Berger E, Rust J \& Scheer C (2010). Influence of biochars on flux of N2O and CO2 from Ferrosol. Soil Res 48: 555.

24. Laird D, Fleming P, Wang B, Horton R \& Karlen D (2010). Biochar impact on nutrient leaching from a Midwestern agricultural soil. Geoderma 158: 436.

25. Obia A, Mulder J, Martinsen, Cornelissen G \& Børresen T (2016). In situ effects of biochar on aggregation, water retention and porosity in light-textured tropical soils. Soil \& Tillage Research 155: 35.

26. Kim HS, Kim KR, Yang JE, Ok YS, Owens G, Nehls T, Wessolek G \& Kim KH (2016). Effect of biochar on reclaimed tidal land soil properties and maize (Zea mays L.) response. Chemosphere 142: 153.

27. Liu Z, Chen X, Jing Y, Li Q, Zhang J \& Huang Q (2014). Effects of biochar amendment on rapeseed and sweet potato yields and water stable aggregate in upland red soil. Catena 123: 45.

28. Laghari M, Mirjat MS, Hu Z, Fazal S, Xiao B, Hu M, Chen Z \& Guo D (2015). Effects of biochar application rate on sandy desert soil properties and sorghum growth. Catena 135: 313.

29. Herath H, Camps-Arbestain M \& Hedley M (2013). Effect of biochar on soil physical properties in two contrasting soils: an Alfisol and an Andisol. Geoderma 209: 188.

30. Liang B, Lehmann J, Solomon D, Kinyangi J, Grossman J, O'neill B, Skjemstad J, Thies J, Luizao F \& Petersen J (2006). Black carbon increases cation exchange capacity in soils. Soil Sci Soc Am J 70: 1719.

31. Freddo A, Cai C \& Reid BJ (2012). Environmental contextualisation of potential toxic elements and polycyclic aromatic hydrocarbons in biochar. Environ Pollut 17: 18.

32. Beesley L, Moreno-Jimenez E, GomezEyles JL, Harris E, Robinson B \& Sizmur $T$ (2011). A review of biochars' potential role in the remediation, revegetation and restoration of contaminated soils. Environ 
Pollut 159: 3269.

33. Ogbonnaya U \& Semple KT (2013). Impact of biochar on organic contaminants in soil: a tool for mitigating risk. Agronomy 3: 349.

34. Yuan JH, Xu RK, Qian W \& Wang RH (2011). Comparison of the ameliorating effects on an acidic ultisol between four crop straws and their biochars. J Soils Sediments 11: 741.

35. Jeffery $\mathrm{S}$, Verheijen FGA, Van der Velde $\mathrm{M}$ $\&$ Bastos AC (2011). A quantitative review of the effects of biochar application to soils on crop productivity using meta-analysis. Agric Ecosyst Environ 144: 175.

36. Chan K, Van Zwieten L, Meszaros I, Downie A \& Joseph S (2008). Agronomic values of greenwaste biochar as a soil amendment. Soil Res 45: 629.

37. Han F, Ren L \& Zhang XC (2016). Effect of biochar on the soil nutrients about different grasslands in the Loess Plateau. Catena 137: 554.

38. Wang R, Kang Y \& Wan S (2015). Effects of different drip irrigation regimes on saline-sodic soil nutrients and cotton yield in an arid region of Northwest China. Agric Water Manage 153 : 1.

39. DeLuca T, MacKenzie M, Gundale M \& Holben W (2006). Wildfire-produced charcoal directly influences nitrogen cycling in ponderosa pine forests. Soil Sci Soc Am J 70: 448.

40. Smider B, Singh B (2014). Agronomic performance of a high ash biochar in two contrasting soils. Agric Ecosyst Environ 191: 99.

41. Zhao X, Wang J, Wang S \& Xing G (2014). Successive straw biochar application as a strategy to sequester carbon and improve fertility: A pot experiment with two rice/wheat rotations in paddy soil. Plant
Soil 378: 279.

42. Jaafar NM, Clode PL \& Abbott LK (2014). Microscopy observations of habitable space in biochar for colonization by fungal hyphae from soil. J Integr Agric 13: 483.

43. Quilliam RS, Glanville HS, Wade SC \& Jones DL (2013). Life in the 'charosphere'-Does biochar in agricultural soil provide a significant habitat for microorganisms. Soil Biol Biochem 65: 287.

44. Gul S, Whalen KJ, Thomas BW, Sachdeva V \& Deng H (2015). Physico-chemical properties and microbial responses in biochar-amended soils: Mechanisms and future directions, Agric. Ecosyst Environ 206: 46.

45. Shen Z, Som AM, Wang F, Jin F, McMillan O \& Al-Tabbaa A (2016). Long-term impact of biochar on the immobilisation of nickel (II) and zinc (II) and the revegetation of a contaminated site. Sci Total Environ 542: 771.

46. Oleszczuk P, Hale SE, Lehmann J \& Cornelissen G (2012). Activated carbon and biochar amendments decrease porewater concentrations of polycyclic aromatic hydrocarbons (PAHs) in sewage sludge. Bioresour Technol 111: 84.

47. Wang H, Lin K, Hou Z, Richardson B \& Gan J (2010). Sorption of the herbicide terbuthylazine in two New Zealand forest soils amended with biosolids and biochars. J Soils Sediments 10: 283.

48. Sparkes J \& Stoutjesdijk P (2011). ABARES.

49. Güereña D, Lehmann J, Hanley K, Enders A, Hyland C \& Riha S (2013). Nitrogen dynamics following field application of biochar in a temperate North American maize-based production system. Plant Soil 365: 239 . 